\title{
Analisis Kualitas Aspek Laboratorium Buku Teks Mata Pelajaran Fisika SMA Kelas XI Kurikulum 2013 Menggunakan Instrumen Science Textbook Rating System
}

\author{
Fatihah Suci Sholihah Annur Jannah ${ }^{1}$, Zeni Haryanto ${ }^{2}$, dan Muliati Syam ${ }^{3}$ \\ 1*Program Studi Pendidikan Fisika, FKIP, Universitas Mulawarman

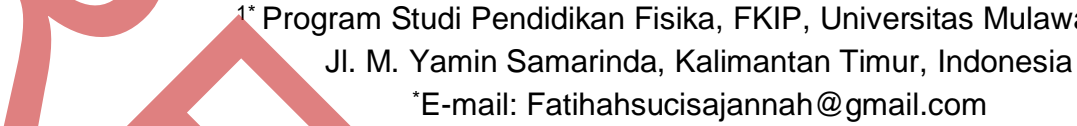 \\ *E-mail: Fatihahsucisajannah@gmail.com
}

\begin{abstract}
Abstrak
Penelitian ini bertujuan untuk: (1) mendeskripsikan kesesuaian buku teks mata pelajaran fisika SMA kelas XI kurikulum 2013 menggunakan instrumen Science Textbook Rating System (STRS) khususnya pada aspek kegiatan laboratorium (2) mendeskripsikan kualitas buku teks mata pelajaran fisika SMA kelas XI kurikulum 2013 menggunakan instrumen Science Textbook Rating System (STRS) khususnya pada aspek laboratorium. Jenis penelitian ini adalah penelitian deskriptif dengan pendekatan evaluatif yang mendeskripsikan isi buku. Teknik pengumpulan data yang digunakan dalam penelitian ini dengan menggunakan instrumen Science Textbook Rating System (STRS). Hasil penelitian ini menunjukkan bahwa (1) buku ini memiliki tingkat kesesuaian berdasarkan instrumen Science Textbook Rating System (STRS) khususnya pada aspek kegiatan laboratorium sebesar $78 \%$. (2) buku ini memiliki kualitas baik (B) berdasarkan instrumen Science Textbook Rating System (STRS) khususnya pada aspek laboratorium. Penelitian ini diharapkan dapat menjadi salah satu pedoman oleh guru dan siswa dalam memilih buku teks yang akan digunakan sebagai sumber belajar setelah semua aspek diteliti untuk buku yang sama.
\end{abstract}

Kata kunci: Kualitas, Buku Teks, STRS, Aspek Laboratorium.

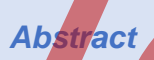

This study aims to: (1) describe the suitability of the textbooks for high school physics subject for class XI in the 2013 curriculum using the Science Textbook Rating System (STRS) instrument, especially in the aspect of laboratory activities (2) to describe the quality of the textbooks for high school physics subject for class XI in the 2013 curriculum using the Science Textbook Rating System (STRS) instrument, especially in the laboratory aspect . This type of research is a descriptive study with an evaluative approach that describes the contents of the book. Data collection techniques used in this study using the Science Textbook Rating System (STRS) instrument. The results of this study indicate that (1) this book has a suitability level based on the Science Textbook Rating System (STRS) instrument, especially in the aspect of laboratory activities by 78\%. (2) this book has good quality (B) based on the Science Textbook Rating System (STRS) instrument, especially on the laboratory aspect. This research is expected to be one of the guidelines for teachers and students in choosing textbooks that will be used as learning resources after all aspects are examined for the same book.

Keywords: Quality, Textbooks, STRS, Laboratory Aspects.

Article History: Received: 22 April 2021

$\begin{array}{cc}\text { Accepted: } 26 \text { November } 2021 & \text { Published: } 30 \text { November } 2021 \\ \text { How to cite: Jannah, F.S.S.A., Haryanto, Z, dan Syam, M. (2021). Analisis Kualitas Aspek Laboratorium Buku }\end{array}$ Teks Mata Pelajaran Fisika SMA Kelas XI Kurikulum 2013 Menggunakan Insrumen Science Textbook Rating System, Jurnal Pendidikan Fisika, 2 (2). pp. 99-107. Retrieved from http://jurnal.fkip.unmul.ac.id/index.php/JLPF

Copyright (C) November 2021, Jurnal Literasi Pendidikan Fisika 


\section{PENDAHULUAN}

Pelajaran fisika dalam proses pembelajaran di kelas, harus disajikan secara utuh agar siswa mampu memahami fakta ilmiah dan juga mampu untuk memahami dan menghayati nilai-nilai ilmiah yang akan terwujud dalam sikap dan perilaku ilmiah. Supaya hal ini dapat terealisasikan maka siswa dituntut untuk terlibat aktif dalam proses-proses ilmiah saat pembelajaran fisika berlangsung. Hal ini juga terkait dengan pengertian fisika secara utuh yakni, fisika merupakan sebuah upaya untuk menemukan sesuatu dengan sikap dan metode ilmiah. Jadi, dalam hal ini pembelajaran fisika memiliki kemampuan untuk dapat menggali rahasia alam dan juga pola keteraturannya. Jika kemudian semua ini telah dapat dilakukan dengan baik saat pembelajaran fisika, maka siswa akan mampu menjadi generasi yang berperan sebagai problem solver pada tiap permasalahan yang ada, baik sekarang maupun permasalahan yang akan datang.

Berkaitan dengan hal tersebut pendidikan nasional menurut Undang-undang No. 23 (2003) memiliki fungsi untuk mengembangkan dan membentuk watak serta peradaban bangsa yang bermartabat dalam rangka mencerdaskan kehidupan bangsa. Dalam dunia pendidikan jenjang sekolah buku teks hadir sebagai sarana dalam membantu mewujudkan harapan-harapan tersebut. Buku teks yang tersedia seharusnya lebih menekankan pada penalaran sehingga siswa diharapkan mampu memahami dan menguasai konsep. Konsep-konsep tersebut dapat diterapkan secara kreatif untuk dapat menyelesaikan permasalahan nyata yang ada dalam kehidupan sehari-hari.

Peraturan Menteri Pendidikan dan Kebudayaan Republik Indonesia Nomor 8 Tahun 2016 tentang buku yang digunakan oleh satuan pendidikan, menyebutkan bahwa buku teks pelajaran merupakan buku acuan wajib yang digunakan di sekolah yang memuat materi pelajaran dalam rangka peningkatan keimanan dan ketakwaan, budi pekerti dan kepribadian, kemampuan penguasaan ilmu pengetahuan dan tekhnologi, kepekaan dan kemampuan estetis, potensi fisik dan kesehatan yang disusun berdasarkan Standar Nasional Pendidikan. Dengan berlandaskan ini maka kualitas buku teks yang baik maka akan menghasilkan proses dan hasil pembelajaran yang baik.

Menurut Lestari (2013:6) Buku teks adalah bahan tertulis berupa lembaran dan dijilid yang berisi ilmu pengetahuan yang diturunkan dari kompetensi dasar yang ada dalam kurikulum yang berlaku untuk kemudian digunakan oleh siswa). Beragam buku teks sangat banyak beredar di pasaran dari penerbit swasta, termasuk buku teks mata pelajaran fisika untuk SMA/sederajat. Semakin banyak buku yang beredar maka penyeleksian dalam memilih buku pun harus dilakukan secara seksama. Terkait dengan hal ini dalam memilih buku teks yang akan digunakan untuk proses pembelajaran peran dari guru dan siswa dalam menyeleksi buku-buku tersebut sangat dibutuhkan. Penulis telah melakukan observasi beragam buku teks yang beredar di pasaran khususnya di daerah Kota Samarinda yang tertera pada tabel berikut :

Tabel 1. Daftar Buku Fisika Kelas XI

\begin{tabular}{lllc}
\hline No & \multicolumn{1}{c}{ Judul Buku } & \multicolumn{1}{c}{ Pengarang } & Penerbit \\
\hline 1. & Fisika SMA/MA kelas XI Jilid 2 Kelompok & Marthen Kanginan & Erlangga \\
& Peminatan K13 & Bambang Ruwanto & Yudhistira \\
\hline 2. & Fisika SMA Kelas XI & & Yrama \\
\hline 3. & $\begin{array}{l}\text { Buku siswa fisika untuk SMA/MA Kelas XI } \\
\text { kelompok-kelompok peminatan matematika dan } \\
\text { ilmu-ilmu alam }\end{array}$ & $\begin{array}{l}\text { 1. Sunardi } \\
\text { 2. Lilis juarni }\end{array}$ & Widya \\
\hline 4. & Fisika untuk kelas XI & Marthen Kanginan & Erlangga \\
\hline 5. & Mandiri Fisika untuk SMA/MA kelas XI & Ni Ketut Lasmi & Erlangga \\
\hline
\end{tabular}

Indonesia saat ini melaksanakan kurikulum 2013 sebagai acuan dalam menyusun program pembelajaran, buku BSE fisika SMA kurikulum 2013 pun telah ada dan telah dinilai oleh BNSP untuk

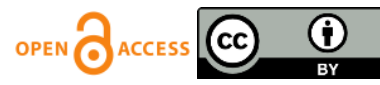


Analisis Kualitas Buku...

kemudian ditetapkan sebagai buku yang layak edar dan dapat dipergunakan oleh siswa dan guru dalam proses pembelajaran. Namun, tak menutup kemungkinan masyarakat juga memilih untuk menggunakan buku terbitan swasta sebagai sumber belajar. Seperti pada wawancara yang telah dilakukan di beberapa sekolah yang ada di Samarinda, meskipun di sekolah siswa dibekali dengan LKS namun ada beberapa sekolah yang menggunakan buku teks fisika BSE, ada pula sekolah yang memilih menggunakan buku teks non BSE sebagai buku pendamping sebagai acuan dalam pelaksanaan proses pembelajaran.

Penilaian buku berskala internasional untuk mata pelajaran IPA seperti instrumen Science Textbook Rating System (STRS) karya Collete dan Chiapetta dalam bukunya yang berjudul Science Instruction in the Middle and Secondary Schools, sedangkan untuk skala nasional adalah BSNP. Dalam Science Textbook Rating System (STRS) kriteria penilaian buku meliputi isi, organisasi buku, tingkat keterbacaan, pemahaman konsep dan prinsip, pendekatan instruksional, ilustrasi, bantuan pembelajaran disetiap akhir bab, kegiatan laboratorium, bantuan untuk guru, indeks dan glosarium dan kenampakan fisik buku teks.

Geene dan Petty dalam Muslich (2010:53) menyatakan bahwa buku teks tersebut dapat menarik minat siswa yang mempergunakannya merupakan salah satu kategori yang harus dipenuhi buku teks yang berkualitas. Salah satu aspek yang dapat menarik siswa dalam buku teks pembelajaran adalah adanya kegiatan laboratorium atau percobaan selain menarik minat siswa dalam belajar adanya kegiatan laboratorium dapat membantu siswa agar dapat memahami konsep dan prinsip fisika dengan tepat.

Hasil penelitian sebelumnya dilakukan dengan membandingkan buku BSE dan Non BSE KTSP memiliki perbedaan kualitas dari kriteria-kriteria penilaian buku teks dalam STRS, pada aspek laboratorium skor tertinggi dimiliki buku non-BSE. Penelitian berbeda dengan penelitian sebelumnya karena penelitian ini akan menganalisis buku teks mata pelajaran fisika kurikulum 2013, sehigga pertanyaan yang muncul pada penelitian ini adalah (1) "Apakah buku teks mata pelajaran fisika SMA kelas XI kurikulum 2013 memiliki kesesuaian berdasarkan kriteria-kriteria yang merujuk pada STRS khususnya pada aspek kegiatan laboratorium?" (2) "Bagaimana kualitas buku teks mata pelajaran fisika SMA kelas XI kurikulum 2013 berdasarkan kriteria-kriteria yang merujuk pada STRS khususnya pada aspek laboratorium?"

\section{METODE}

Jenis penelitian ini adalah penelitian deskriptif dengan pendekatan evaluatif yang mendeskripsikan isi buku. Penelitian ini mendeskripsikan kualitas buku teks mata pelajaran fisika SMA kelas XI kurikulum 2013 terbitan swasta non-BSE pada aspek kegiatan laboratorium.

Subjek dalam penelitian ini adalah seluruh buku teks mata pelajaran fisika SMA kelas XI kurikulum 2013 terbitan swasta non-BSE. Sampel dalam penelitian ini adalah buku teks mata pelajaran fisika SMA kelas XI kurikulum 2013 terbitan swasta non-BSE pada setiap materi yang menyertakan kegiatan laboratorium. Buku yang akan di analisis adalah buku Fisika SMA/MA kelas XI karya Bambang Ruwanto, penerbit Yudisthira.

Pengambilan sampel dilakukan dengan cara purposive sampling. Purposive sampling disebut juga judgemental sampling, yaitu pengambilan sampel yang didasarkan pada "penilaian" (judgement) atau pengambilan sampel secara sengaja sesuai dengan persyaratan sampel yang diperlukan dan terpilihlah buku Fisika SMA/MA kelas XI karya Bambang Ruwanto, penerbit Yudisthira pada tiap materi yang menyertakan kegiatan laboratorium.

Pengumpulan data dilakukan dengan menggunakan instrumen STRS karya Collette \& Chiapetta (1994:319-321) pada aspek kegiatan laboratorium yang telah dimodifikasi oleh Septiana Karumaningrum dan telah divalidasikan kepada ekspert judgement dosen Pendidikan Fisika FMIPA UNY.

Analisis data dan hipotesis yang dilakukan pada penelitian ini adalah dengan menjumlahkan skor dari hasil set coding untuk setiap kriteria, sehingga diperoleh skor total dari penilaian aspek dengan

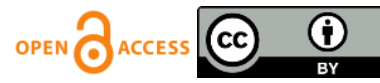


skor maksimal 50 dan skor minimal 10 kemudian, skor akan di interpretasikan berdasarkan kategori skor yang dapat dilihat pada tabel 2 seperti berikut:

Tabel 2. Kategori Skor

\begin{tabular}{ccc}
\hline No & Interval nilai & Kategori Skor \\
\hline $\mathbf{1}$ & $10-20$ & $\mathrm{D}$ (buruk) \\
\hline $\mathbf{2}$ & $21-30$ & $\mathrm{C}$ (cukup) \\
\hline $\mathbf{3}$ & $31-40$ & $\mathrm{~B}$ (baik) \\
\hline $\mathbf{4}$ & $41-50$ & $\mathrm{~A}$ (sangat baik) \\
\hline
\end{tabular}

(Asri, 2019 : 24)

Dari skor total yang diperoleh akan menghasilkan skor untuk penilaian dari kualitas buku teks yang diteliti, sedangkan untuk persentase kesesuaian dari buku teks, dapat diperoleh dengan menggunakan persamaan yang ditulis oleh (Tegeh et al., 2014) dalam bukunya yang berjudul pengembangan model penelitian.

\section{HASIL DAN PEMBAHASAN}

HASIL

Setelah dilakukan penilaian terhadap sampel peneilitian oleh peneliti, maka diperoleh hasil penilaian aspek kegiatan laboratorium yang dapat di lihat pada gambar 1 sebagai berikut:

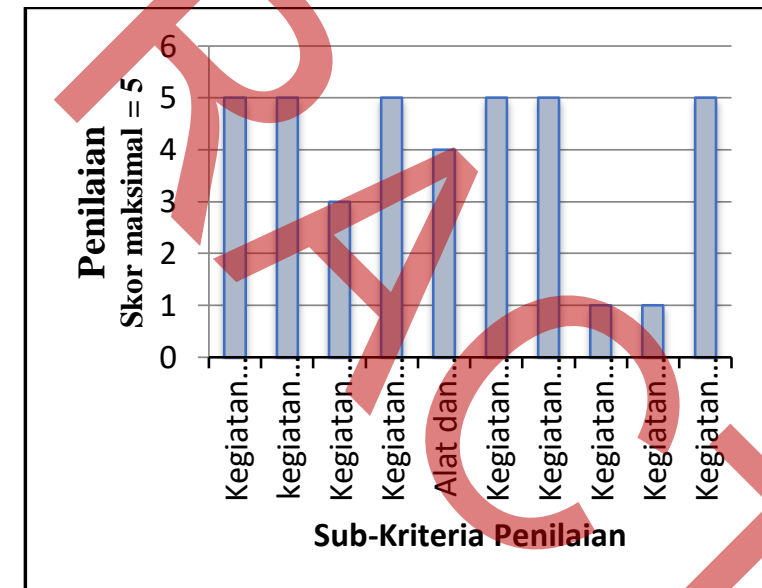

Gambar 1. Hasil Penilaian Buku Teks Pada Aspek Kegiatan Laboratorium

Hasil analisis penilaian buku teks pada aspek kegiatan laboratorium pada buku buku Fisika SMA/MA kelas XI karya Bambang Ruwanto diperoleh jumlah skor total sebesar 39, dengan demikian buku tersebut merupakan buku berkategori baik (B) pada aspek yang diteliti, yakni aspek kegiatan laboratorium. Kemudian buku tersebut memiliki tingkat kesesuaian sebesar $78 \%$.

\section{PEMBAHASAN}

Tujuan dari penelitian kali ini adalah untuk mendeskripsikan kualitas buku teks mata pelajaran fisika SMA/MA kelas XI Kurikulum 2013. Buku yang diteliti adalah buku karangan Bambang Ruwanto. Buku ini termasuk dalam kategori baik (B) dengan skor total 39 yang ditinjau dari aspek kegiatan laboratorium yang terdiri dari 21 percobaan.

Pada Bab 1 materi Dinamika Rotasi dan Keseimbangan Benda Tegar terdapat 3 percobaan. Percobaan pertama penulis cantumkan pada halaman 12-13 mengenai momen inersia. Kegiatan percobaan ini bertujuan untuk memahami besaran momen inersia melalui percobaan sederhana. Setelah melakukan percobaan tersebut siswa mampu untuk mengetahui besaran-besaran apa saja yang bekerja pada momen inersia. Kegiatan percobaan tersebut penulis sajikan dengan menekankan pada aspek investigasi dan dapat dilakukan saat proses pembelajaran di kelas berlangsung dengan

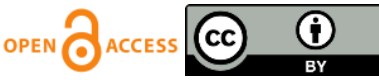


Analisis Kualitas Buku...

menggunakan bolpoin atau pensil yang diputar pada poros yang berbeda. Prosedur kerja yang jelas dan urut disajikan dengan poin, penulis juga mencantumkan gambar percobaan sehingga siswa akan mudah untuk melakukan percobaan.

Percobaan kedua penulis cantumkan pada halaman 17-18 mengenai momen gaya. Percobaan ini bertujuan untuk memahami besaran momen gaya melalui percobaan sederhana. Percobaan ini dilakukan dengan menggunakan sebuah pintu di ruangan, beberapa karet penghisap dan neraca pegas, dimana penulis menekankan aspek investigasi dan dapat dilakukan selama proses belajar mengajar di kelas berlangsung. Prosedur percobaan disusun dengan rinci dimulai dari proses mengamati dan mengumpulkan data, pada proses ini ada dua variabel yang dilakukan yakni variasi posisi karet penghisap pada pintu terhadap engsel dan variasi sudut terhadap engsel yang memengaruhi besar gaya yang dilakukan, penulis juga mencantumkan gambar percobaan yang akan dilakukan, sehingga memberikan kemudahan bagi siswa untuk melakukan percobaan tersebut. Setelah itu siswa diminta untuk menalar dan mengkomunikasikan hasil dari percobaan yang telah mereka lakukan

Percobaan ketiga penulis cantumkan pada halaman 36 mengenai menentukan titik berat benda. Penulis tidak mencantumkan mengenai tujuan dilakukannya percobaan tersebut. Alat dan bahan serta prosedur kerja penulis sajikan secara langkap dan rinci sehingga dapat memudahkan siswa dalam melakukan percobaan, selain itu pada percobaan ini penulis juga mencantumkan gambar sehingga siswa mendapatkan petunjuk selain dari prosedur kerja untuk melakukan percobaan.

Bab 2 pada materi Elastisitas dan Hukum Hooke terdapat 3 percobaan. Percobaan pertama pada halaman 59 mengenai percobaan elastisitas dan plastisitas. Tujuan dari percobaan ini adalah untuk mengamati bahan plastis, Alat dan bahan penulis sajikan dengan jelas, alat dan bahan yang digunakan sederhana, sehingga siswa bisa menyelesaikan percobaan selama proses pembelajaran berlangsung. Prosedur kerja yang ditampilkan pun disajikan secara sistematis, siswa akan melakukan pengamatan terhadap kantong plastik yang diberi muatan batu (anak timbangan) dan tidak.

Percobaan kedua pada halaman 64-65 mengenai elastisitas pegas. Kegiatan percobaan ini bertujuan untuk menentukan hubungan antara besar gaya dan pertambahan panjang pegas. Penulis menuliskan alat dan bahan serta rangkaian percobaan agar siswa mudah melakukan percobaan. Prosedur percobaan penulis sajikan dalam bentuk poin sehingga siswa akan mudah untuk mengikuti langkah demi langkah dalam melakukan percobaan. Penulis juga menyajikan tabel pengamatan pada percobaan ini untuk memudahkan siswa dalam mengambil dan menganalisis data. Selain itu penulis juga mencantumkan grafik setelah percobaan dilakukan.

Percobaan ketiga penulis mencantumkan pada halaman 68-69 mengenai susunan pegas seriparalel. Tujuan dai percobaan ini adalah untuk menentukan konstanta pegas pengganti susunan seriparalel. Percobaan ini dilakukan dengan dua variabel bebas yaitu rangkaian seri pada pegas dan rangkaian paralel pada pegas. Penulis menyajikan alat dan bahan secara terperinci, dan prosedur kerja yang disusun berdasarkan masing-masing percobaan juga memudahkan siswa untuk melakukan percobaan. Percobaan ini tidak dilengkapi gambar percobaan dan juga tabel pengamatan.

Pada bab 4 pada materi Fluida terdapat 5 percobaan. Percobaan pertama ditulis pada halaman 77 78 mengenai tekanan hidrostatik. Percobaan ini bertujuan untuk memahami tekanan hidrostatik pada fluida, alat dan bahan yang digunakan sangat sederhana dan mudah ditemukan, percobaan ini juga dilengkapi dengan gambar percobaan serta prosedur kerja yang sistematis sehingga siswa dapat dengan mudah untuk menyelesaikan percoban. Siswa juga diminta untuk memberikan simpulan dari percobaan yang telah dilakukan.

Percobaaan kedua ditulis pada halaman 85 mengenai hukum Archimedes. Tujuan dari kegiatan percobaan ini adalah untuk mengamati hukum Archimedes dengan melihat adanya gaya ke atas (gaya apung) yang dikerjakan fluida. Alat dan bahan penulis sajikan dalam bentuk list penomoran. Kegiatan percobaan ini juga menekankan aspek investigasi dan melibatkan keterampilan siswa yang terkait dengan kemampuan manipulatif siswa yang sesuai pada tingkat kelasnya. Pada percobaan ini siswa diberi tantangan untuk merangkai alat dan bahan melalui prosedur kerja, untuk memudahkan siswa

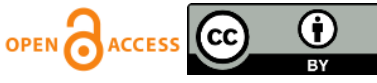


Analisis Kualitas Buku...

dalam meneyelesaikan tantangan tersebut, penulis mencantumkan gambar ilustrasi dari percobaan yang akan dilakukan. Setelah itu siswa dituntut untuk memberikan simpulan dari hasil percobaan yang telah dilakukan.

Percobaan ketiga penulis mencantumkan pada halaman 88-89 mengenai kapilaritas. Tujuan dari pelaksanaan percobaan ini adalah untuk mengamati peristiwa kapilaritas pada air. Alat dan bahan penulis cantumkan dengan format penomoran, penulis juga memberikan ilustrasi dari gambar percobaan serta prosedur kerja yang disajikan dalam bentuk penomoran sistematis akan memudahkan siswa dalam menyelesaikan percobaan. Percobaan ini mungkin dilakukan selama proses pembelajaran berlangsung.

Percobaan keempat ditulis pada halaman 94 mengenai asas Bernoulli. Tujuan dari percobaan ini adalah untuk mengamati asas Bernoulli dalam keseharian. Kegiatan percobaan ini hanya dilakukan dengan alat sederhana berupa selembar kertas, adanya gambar ilustrasi dan prosedur kerja yang rinci membuat siswa mudah untuk menyelesaikan percobaan. Percobaan ini sangat mungkin untuk dilakukan selama kelas berlangsung maupun saat siswa belajar di rumah.

Percobaan kelima penulis mencantumkan pada halaman 100 mengenai sifat kekentalan (viskositas) sebuah cairan. Tujuan dari percobaan ini adalah untuk mengamati sifat viskositas beberapa cairan. Alat dan bahan penulis cantumkan secara rinci dengan list berupa penomoran. Penulis juga mencantumkan prosedur kerja secara sistematis, selain itu adanya tabel pengamatan dalam percobaan ini akan memudahkan siswa dalam mengambil data dan mengolah data.

Bab 4 Suhu dan Kalor terdiri dari 6 percobaan. Percobaan pertama penulis mencantumkan pada halaman 114 mengenai koefisien muai panjang. Penulis menuliskan tujuan dari percobaan kali ini adalah untuk menentukan koefisien muai panjang logam. Pada percobaan ini alat dan bahan penulis rincikan dengan bentuk penomoran. Prosedur kerja yang disajikan dengan bentuk sistematis dan jelas, siswa dituntut untuk merangkai alat dan bahan secara mandiri namun penulis membantu mudahakan siswa dengan memberikan ilustrasi dari rangkaian gambar alat dan bahan yang harus disusun siswa. Percobaan ini dilakukan beberapa kali pengambilan data dengan jenis logam yang berbeda, sayang nya penulis tidak memberikan tabel pengamatan agar memberikan kemudahan kepada siswa dalam mengambil data percobaan.

Pada halaman 122-123 penulis menuliskan percobaan mengenai menggambar grafik pendinginan Napthalena (lilin). Kegiatan laboratorium ini bertujuan untuk mengamati perubahan wujud, alat dan bahan penulis sajikan dalam bentuk list penomoran, penulis juga mencantumkan prosedur kerja secara sistematis dan gambar dari rangkaian alat dan bahan sehingga memudahkan siswa untuk melakukan kegiatan laboratorium. Kegiatan ini dapat dilaksanakan saat proses pembelajaran berlangsung.

Pada halaman 123-124 penulis menuliskan percobaan dengan judul kalor jenis. Tujuan dari kegiatan percobaan kalor jenis adalah untuk menentukan kalor jenis dari berbagai bahan, yaitu besi, alumunium dan tembaga. Penulis mencantumkan alat dan bahan dalam bentuk list, prosedur kerja disusun secara runtut oleh penulis untuk memudahkan siswa dalam melakukan percobaan. Penulis juga memberikan pertanyaan di akhir hingga siswa akan lebih mudah untuk menarik kesimpulan, namun penulis tidak mencantumkan tabel pengamatan.

Penulis mencantumkan percobaan keempat pada halaman 127 mengenai konduktivitas termal. Penulis menuliskan tujuan dari kegiatan percobaan ini adalah untuk membandingkan konduktivitas kalor beberapa benda. Alat dan bahan penulis sajikan dengan jelas melalui list penomoran, prosedur kerja juga disusun secara sistematis sehingga akan memudahkan siswa untuk melakukan percobaan, percobaan ini dapat dilaksanakan secara langsung di kelas. Pada halaman 128 penulis menuliskan percobaan mengenai Perpindahan kalor secara konveksi. Percobaan ini bertujuan untuk mengamati arus kalor secara konveksi. Penulis menuliskan alat dan bahan dan prosedur kerja secara sistematis sehingga siswa lebih mudah untuk melakukan percobaan.

Percobaan keenam ditulis pada halaman 130 dengan judul perpindahan kalor secara radiasi. Tujuan dari percobaan ini adalah untuk mengamati perpindahan kalor secara radiasi. Penulis menuliskan alat dan bahan serta prosedur kerja secara sistematis sehingga siswa akan lebih mudah dalam melakukan 
Analisis Kualitas Buku...

percobaan.

Bab 5 Teori Kinetik Gas hanya terdapat 1 percobaan. Percobaan ini penulis sajikan pada halaman 141-141 mengenai Hukum Boyle, kegiatan percobaan ini bertujuan untuk mengamati peristiwa seharihari yang menjelaskan hukum boyle. Penulis menuliskan alat dan bahan dengan jelas dan prosedur percobaan secara rinci, penulis juga mencantumkan gambar percobaan yang memudahkan siswa untuk melakukan investigasi sehingga diperoleh simpulan dari percobaan yang telah dilakukan.

Bab 6 mengenai Hukum Termodinamika terdapat 1 percobaan. Pada halaman 164 ditulis percobaan mengenai Hukum I Termodinamika. Pada percobaan ini penulis tidak mencantumkan tujuan, alat dan bahan dan prosedur kerja. Penulis memanfaatkan virtual laboratorium untuk melakukan percobaan, penulis hanya memberikan link untuk mengakses virtual laboratorium dan menyertakan pertanyaan yang harus disimpulkan siswa setelah melakukan percobaaan.

Bab 7 pada materi Gelombang tidak ada percobaan. Bab 8 tentang materi Gelombang Bunyi hanya terdapat 1 percobaan yang ada pada halaman 216. Penulis tidak menuliskan judul dan tujuan percobaan, alat dan bahan serta prosedur kerja disusun dengan paragraf sehingga siswa kesulitan untuk melakukan percobaan, akan tetapi penulis menuliskan pertanyaan pada akhir percobaan agar siswa lebih mudah dalam mengambil kesimpulan data, menganalisis dan menarik kesimpulan.

Bab 9 materi Gelombang Cahaya tidak ada percobaan. Bab 10 mengenai Optika Geometris terdapat 1 percobaan yang ditulis pada halaman 287-288 dengan judul membuat teleskop sederhana. Penulis tidak mencantumkan tujuan dari percobaan, tetapi penulis mencantumkan tinjauan umum dari pelaksanaan kegiatan percobaan. Alat dan bahan disusun penulis dengan format list penomoran, langkah percobaan yang disusun secara sistematis dan dilengkapi dengan gambar percobaan memudahkan siswa untuk melakukan percobaan dan pada bab 11 mengenai Pemanasan Global tidak terdapat kegiatan percobaan.

Buku Fisika SMA/MA kelas XI karya Bambang Ruwanto ini termasuk dalam kategori baik yang ditinjau dari aspek kegiatan laboratorium.Dalam buku ini yang mendapat kategori sangat baik pada aspek kegiatan laboratorium yang artinya dalam 21 percobaan aspek ini bernilai sangat baik, antara lain aspek tersebut adalah kegiatan laboratorium sesuai dengan aspek penguasaan kognitif siswa, kegiatan laboratorium melibatkan keterampilan siswa, kegiatan laboratorium aman dilakukan siswa, kegiatan laboratorium sesuai dengan substansi materi yang ditampilkan, kegiatan laboratorium tercakup dalam uraian bahan/materi yang ditampilkan dan aspek kegiatan laboratorium sejalan dengan uraian materi pelajaran dan berhubungan dengan pedoman kegiatan.

Pada keriteria alat dan bahan yang tersedia untuk menunjang kegiatan percobaan, buku ini mendapat kategori baik, karena ada 1 percobaan, yakni pada percobaan di bab 6 mengenai Hukum Termodinamika 1 penulis tidak menyertakan alat dan bahan.

Pada kriteria kegiatan laboratorium menekankan aspek investigasi, buku ini mendapat kategori cukup karena terdapat 2 kegiatan laboratorium yang menekankan tentang hal tersebut dan untuk kategori kegiatan laboratorium mencakup petunjuk kegiatan laboratorium yang terpisah bukuini juga mendapatkan kategori sangat buruk karena tidak adanya petunjuk kegiatan yang terpisah, sedangkan dalam penilaian STRS karya Collete \& Chiapetta (1994:32) yang mengemukakan bahwa setiap buku teks hendaknya menyertakan buku khusus yang diberisi petunjuk kegiatan laboratorium.

Pada aspek kegiatan laboratorium dapat dilakukan selama kelas berlangsung mendapat kategori sangat buruk karena terdapat tiga kegiatan laboratorium yang tidak dapat dilakukan selama pembelajaran kelas berlangsung.

Buku Fisika SMA/MA kelas XI karya Bambang Ruwanto ini masih terdapat kekurangan yakni pada bagian tabel data dari hasil percobaan yang tidak terdapat dalam semua kegiatan laboratorium yang penulis sajikan, selain itu merujuk pada buku berjudul Physics Principles and Problems oleh A Glencoe program menuliskan bahwa setiap kegiatan laboratorium hendaknya menyertakan catatan atau label Safety Precautions tentang keamanan kegiatan laboratorium yang akan dilakukan, kemudian pada buku berjudul Eksperiment in General Chemistry : Inquiry and Skill Building karya Vickie Williamson and Larry Peck menuliskan bahwa kegiatan laboratorium berbasis inkuiri memiliki tahapan pra-lab yaitu 
tahapan yang dilakukan sebelum dilaksanakannya kegiatan praktikum, dimana peserta didik diberi pertanyaan atau soal yang terkait dengan kegiatan percobaan yang akan dilakukan untuk melihat kemampuan awal peserta didik sebelum dilaksanakannya kegiatan praktikum, kemudian setelah kegiatan laboratorium telah dilaksanakan peserta didik diberi tahapan pasca-lab, dimana peserta didik akan diberi pertanyaan atau soal seputar kegiatan laboratorium yang telah dilaksanakan, untuk melihat kemampuan peserta didik setelah diaksanakannya kegiatan laboratorium atau percobaan, kedua hal dari buku rujukan tersebut tidak penulis cantumkan pada lembar kegiatan laboratorium dalam buku teks ini.

Selain kekurangan tersebut tentunya buku Fisika SMA/MA kelas XI karya Bambang Ruwanto ini juga memiliki kelebihan yaitu lengkapnya bagian tujuan, list alat dan bahan, gambar rangkaian percobaan, prosedur kerja yang penulis sajikan secara rinci serta pertanyaan dan tugas yang dapat memberikan kemudahan bagi siswa untuk melakukan percobaan, menganalisis data dan menarik kesimpulan dari tiap percobaan. Berdasarkan penelitian yang telah dilakukan, penulis dapat merekomendasikan buku Fisika SMA/MA kelas XI karya Bambang Ruwanto cukup baik untuk digunakan sebagai bahan ajar kegiatan laboratorium di kelas dengan catatan guru memiliki buku atau sumber prosedur kegiatan laboratorium terpisah.

\section{PENUTUP}

Berdasarkan hasil penelitian dan pembahasan maka dapat ditarik kesimpulan bahwa buku Fisika SMA/MA kelas XI karya Bambang Ruwanto memiliki tingkat kesesuaian pada kriteria yang merujuk pada STRS yakni pada aspek kegiatan laboratorium sebesar $78 \%$, dan buku Fisika SMA/MA kelas XI karya Bambang Ruwanto memiliki kualitas baik (B) berdasarkan kriteria-kriteria yang merujuk pada STRS khususnya pada aspek laboratorium.

Saran bagi peneliti selanjutnya adalah pada instrumen penelitian diperlukan adanya indikator dari masing-masing sub-kriteria penilaian dan pengembangan pada instrumen yang disesuaikan dengan penilaian kegiatan laboratorium dengan referensi buku kegiatan laboratorium setidaknya 5 tahun terakhir, kemudian perlu adanya analisis perbandingan kegiatan laboratorium dari berbagai buku teks fisika dan analisis lanjutan pada buku ini dilakukan dengan menggunakan aspek STRS yang lain sehingga dapat membantu guru dan siswa dalam memilih buku teks yang digunakan sebagai bahan ajar dalam proses pembelajaran.

\section{DAFTAR PUSTAKA}

Collete A. T \& Chiapetta E. L. (1994). Science Introduction in The Middle and Secondary Schools. New York: Macmillan Publishing

Depdiknas. (2005). Peraturan Menteri Pendidikan Nasional Republik Indonesia No 11 Tahun 2005 tentang Buku Teks Pelajaran. In Departemen Pendidikan Nasional

Glencoe. (2004). Physics Principles and Problems. The McGraw-Hill Compnis. Columbus

Greene dan Petty. (1981). Developing Language Skill in The Elementary Schools. Boston: Alyn and Bacon Inc

Ika Lestari. (2013). Pengembangan Bahan Ajar Berbasis Kompetensi. Jakarta: Akademia Permata.

Karumaningrum, Septiana. (2017). Perbandingan Kualitas BSE dan Non-BSE pada Mata Pelajaran Fisika SMA Kelas X: Telaah Menggunakan Instrumen STRS. Fakultas Matematika dan IImu Pengetahuan Alam. Yogyakarta. Universitas Negeri Yogyakarta

Masnur Muslich. (2010). Textbook Writing: Dasar-dasar Pemahaman, Penulisan dan Pemakaian Buku Teks. Jogjakarta: Ar-Ruzz

Ruwanto, Bambang. (2017). Fisika 2 SMA Kelas XI. Jakarta: Yudhistira

Satiti,Asri. (2019). Analisis Kualitas Buku Teks Mata Pelajaran Fisika Untuk SMA Kelas XI Dengan Menggunakan Instrumen STRS. Fakultas Matematika dan IImu Pengetahuan Alam. Yogyakarta. Universitas Negeri Yogyakarta

Tegeh, I. M., Jampel, I. N., \& Pudjawan, K. (2014). Model penelitian pengembangan. Yogyakarta: Graha IImu.

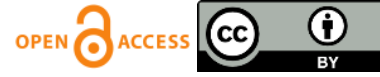


Analisis Kualitas Buku...

UU RI No. 20 Tahun 2003 . (2003). Sistem Pendidikan Nasional.

Williamson, Vickie dan Larry Peck. (2009). Eksperiment in General Chemistry : Inquiry and Skill Building. Brooks/Cole. Cengage Learning

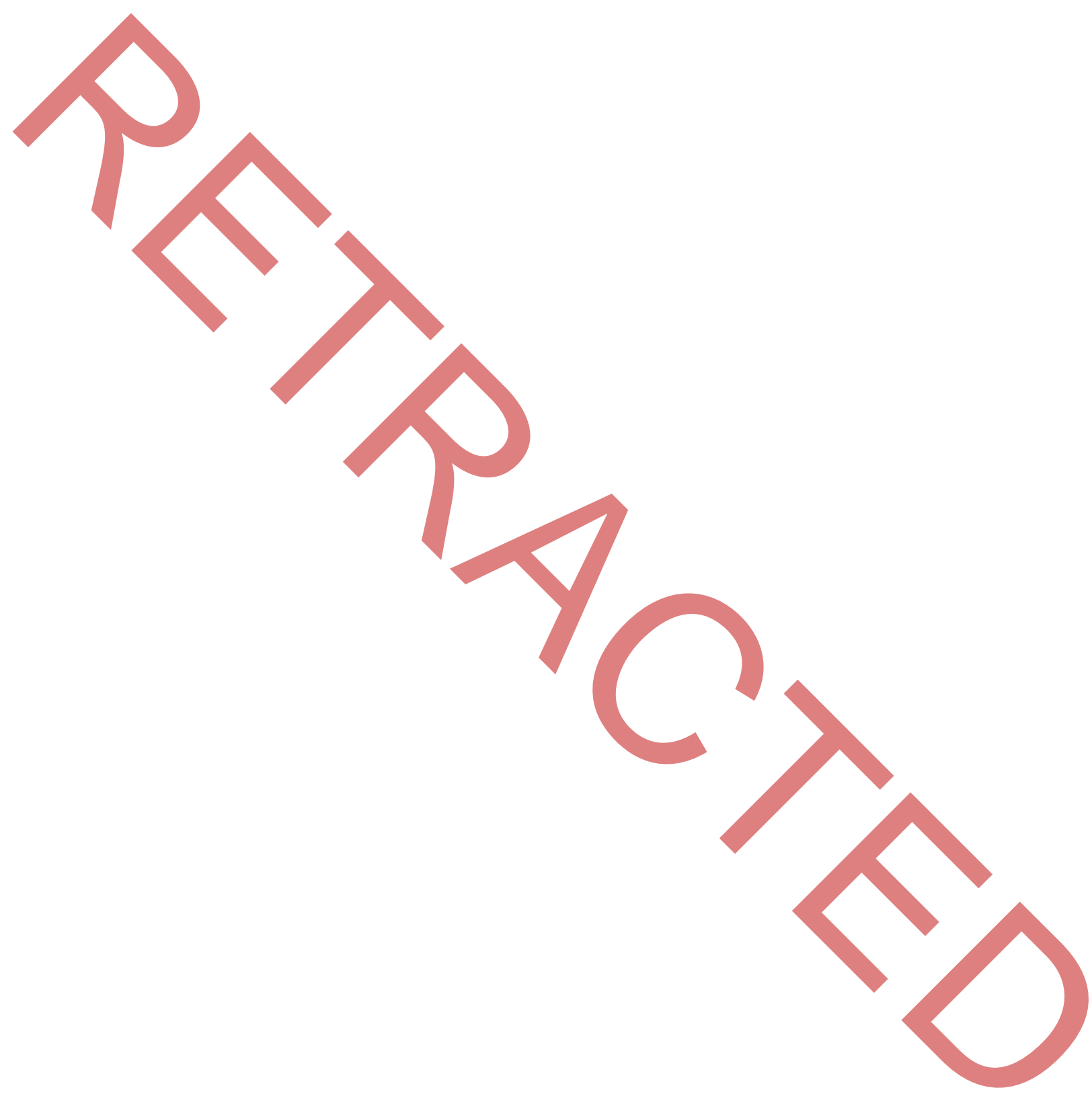

